\title{
Small Mammal Populations in an Unburned and Early Fire Successional Sagebrush Community
}

\author{
JOHN M. MCGEE
}

\author{
Abstract
}

Species composition and total numbers of small mammals changed little in the unburned sagebrush while individual species capture rates varied considerably. Following spring burning, the number of small mammal species and abundance were slightly lower than control levels and were near unburned levels after 3 years. Species composition was greatly reduced on the fall burn in the first postburn year. Two years after burning four species were captured, although only two were caught in live-traps. Total small mammal density increased dramatically in the first two postburn years. The large increase in abundance on both burns was due primarily to Peromyscus maniculatus and Spermophilus armatus. Food use patterns on the fall burn were similar to those observed on the spring burn where small mammals utilized their preferred food types in relation to its abundance and availability.

Prescribed burning of sagebrush (Artemisia tridentata) to increase livestock forage, type conversion, and wildlife habitat improvement is becoming commonplace throughout the Intermountain Region. Management of sagebrush communities with fire for livestock or wildlife requires information on the interrelationships between plants and animals in the postburn stages to better understand successional relationships.

Lawrence (1966) indicated species composition was altered but small mammal abundance was not decreased following fire in chaparral. Stout et al. (1971) reported that densities of small mammals were not unusually high in a burned coniferous forest in northern Idaho. In addition, Taylor (1969) showed the number of small mammal species increased during the first 25 years following fire in lodgepole pine (Pinus contorta) forests in Yellowstone National Park. There are no existing studies on the effects of fire on small mammal populations in sagebrush communities in the Intermountain Region.

This study determines species composition, abundance, and food habits of small mammals in an unburned sagebrush community along with changes in these parameters following prescribed spring and fall burns.

\section{Study Areas and Methods}

\section{Study Areas}

The study areas were on Burro Hill about $40 \mathrm{~km}$ northwest of Jackson, Wyoming, within the Buffalo District, Bridger-Teton

\footnotetext{
Author is wildlife biologist, Targhee National Forest, P.O. Box 228, Ashton, Idaho 83420 .

This research (Eisenhower Consortium Journal Series No. 35) was supported, in part, by the U.S. Dep. Agr. Forest Service through the Eisenhower Consortium for Western Environmental Forestry Research. Financial aid was also provided by the No. Kocky Mtn. Coop. Park Study Prog., the Old West Reg. Comm., and the New York Zool. Soc. Field work was conducted at the Jackson Hole Biol. Res. Sta. The author thanks Jack Dieterick, Harold Edwards, George Gruell, and Dave Patton of the Forest Service for editorial and logistical support. Special thanks are extended to Nancy Stant on, Univ. Wyoming. At the time of the research, the author was graduate student, Dept. of Zoology and Physiology, Univ. Wyoming, Laramie 82071 .

Manuscript received February 4, 1980 .
}

National Park. In unburned areas mountain big sagebrush (Artemisia tridentata vaseyana) is the most abundant shrub, forming dense, homogeneous stands. The most common grasses are wheatgrasses (Agropyron spp.), Idaho fescue (Festuca idahoensis), bluegrasses (Poa spp.) and needlegrasses (Stipa spp.). Characteristic forbs include yarrow (Archillea millefolium), wild buckwheat (Eriogonum umbellatum), geranium (Geranium spp.), lupine (Lupinus spp.), and northwest cinquefoil (Potentilla gracilis). Grasses and forbs form a continuous understory with few open areas. The sagebrush is bordered by stands of Douglas-fir (Pseudotsugamenziesii) and aspen (Populus tremuloides).
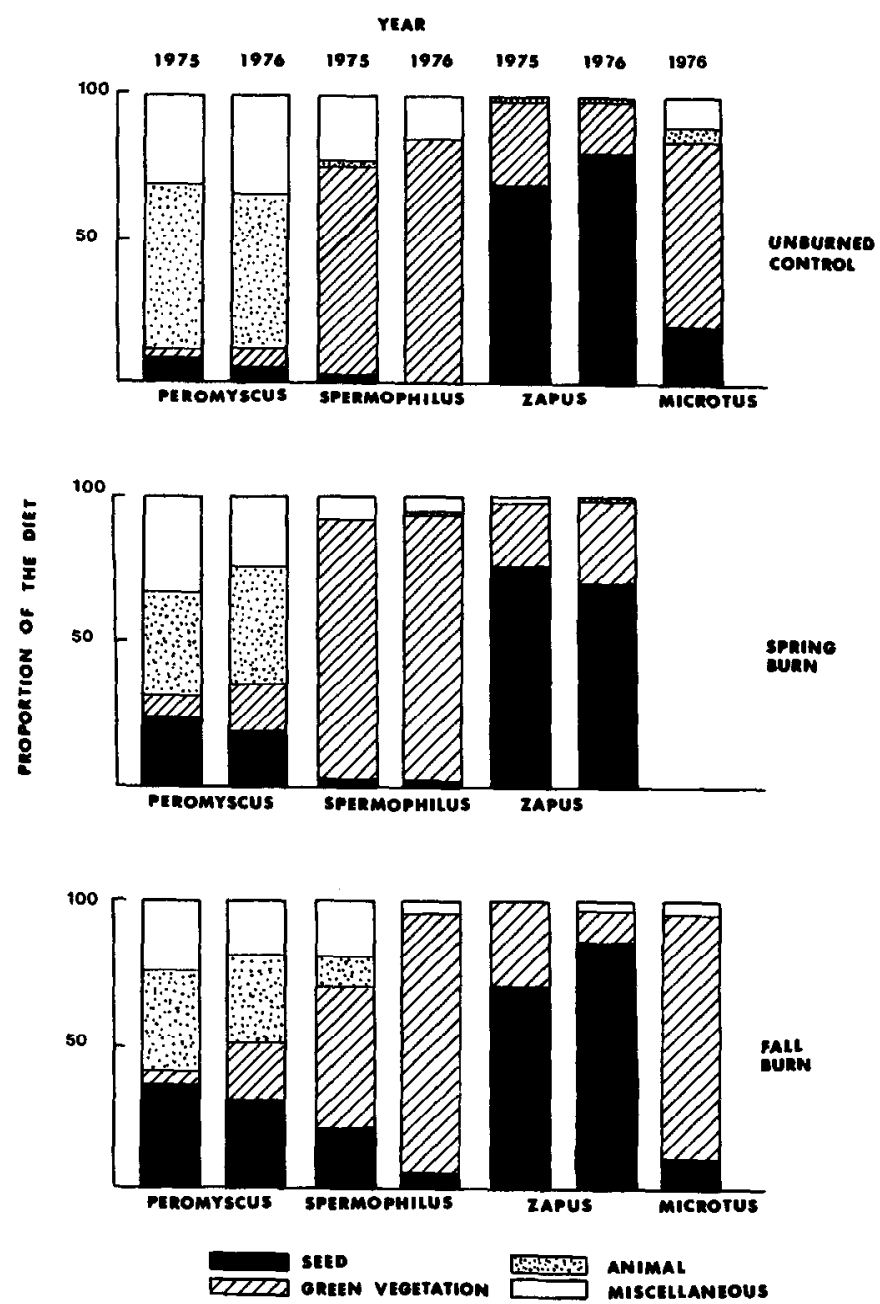

Fig. 1. Proportion of food types in the diets of small mammals. 
On June 3, 1974, 15-20 ha were burned by the Forest Service (spring burn) on the eastern end of Burro Hill, resulting in a mosaic of burned patches ranging from completely burned to partially burned, to unburned. Approximately 70-80 ha were completely burned on August 27, 1974 (fall burn). Approximately 40-50 ha of sagebrush were left unburned along the eastern and western ends of of Burro Hill.

The spring burn was sampled during the first (1974), second (1975), and third (1976) postburn growing seasons. Due to timing of the burns, preburn sampling on the spring burn was not possible. However, the fall burn was sampled in preburn state (1974), and during the first (1975) and second (1976) postburn growing seasons. An unburned control was sampled in all 3 years. It is assumed that preburn conditions on the spring burn plots were not significantly different from those on the fall burn's preburn state and the unburned control.

\section{Sampling}

Plant species composition, frequency of occurrence, and percent cover of understory species were determined using the Daubenmire (1959) canopy coverage method. Forty to fifty quadrats $\left(0.1 \mathrm{~m}^{2}\right)$ were distributed in a stratified random design on each study area based on variations in vegetative distribution. Shrubs were sampled using the line intercept method (Canfield 1941) on ten randomly located $40-\mathrm{m}$ transects.

Small mammals were assessed on five live-trapping grids ( $1.5 \mathrm{ha})$ and five snap-trap removal transects $(500 \mathrm{~m})$ during more than 21,000 trap nights. Animals were live-trapped five consecutive nights each month during June, July, and August. Removal transects were established in 1975 to collect data on food habits and reproduction. Two parallel trap lines were installed on the fall burn and control area, and one line in the spring burn. The relative abundances of small mammals were compared using catch per unit effort (number per 100 trap nights).

Food habits of small mammals from the spring burn were studied in its second (1975) and third (1976) postburn years and from the fall burn in its first (1975) and second (1976). The unburned control was also sampled in 1975 and 1976. Stomach contents of 305 kill-trapped animals were removed, separated under a dissecting microscope, divided into major food groups, (seed, green vegetation, animal) dried, and weighed. The proportion and percent

Table 1. Species composition, total captures, and catch per unit effort (in parentheses expressed as number captured per 100 trap nights) of small mammals on Burro Hill.

\begin{tabular}{|c|c|c|c|c|c|c|c|c|}
\hline \multirow[b]{2}{*}{ Species } & \multicolumn{3}{|c|}{ Live trap } & \multicolumn{2}{|c|}{ Snap trap } & \multicolumn{3}{|c|}{ Totals } \\
\hline & 1974 & 1975 & 1976 & 1975 & 1976 & 1974 & 1975 & 1976 \\
\hline \multicolumn{9}{|l|}{ Unburned control: } \\
\hline Peromyscus maniculatus & $\begin{array}{c}26 \\
(1.7)\end{array}$ & $\begin{array}{c}36 \\
(2.4)\end{array}$ & $\begin{array}{c}50 \\
(2.6)\end{array}$ & $\begin{array}{c}3 \\
(0.2)\end{array}$ & $\begin{array}{c}6 \\
(0.6)\end{array}$ & $\begin{array}{c}26 \\
(1.7)\end{array}$ & $\begin{array}{c}39 \\
(1.9)\end{array}$ & $\begin{array}{c}56 \\
(2.7)\end{array}$ \\
\hline Spermophilus armatus & $\begin{array}{c}18 \\
(1.1)\end{array}$ & $\begin{array}{c}16 \\
(2.5)\end{array}$ & $\begin{array}{c}20 \\
(3.2)\end{array}$ & $\begin{array}{c}6 \\
(0.6)\end{array}$ & $\begin{array}{c}10 \\
(0.9)\end{array}$ & $\begin{array}{c}18 \\
(1.1)\end{array}$ & $\begin{array}{c}22 \\
(1.1)\end{array}$ & $\begin{array}{c}30 \\
(1.5)\end{array}$ \\
\hline Zapus princeps & $\begin{array}{c}17 \\
(1.1)\end{array}$ & $\begin{array}{c}24 \\
(1.6)\end{array}$ & $\begin{array}{c}23 \\
(1.5)\end{array}$ & $\begin{array}{c}5 \\
(0.5)\end{array}$ & $\begin{array}{c}8 \\
(0.7)\end{array}$ & $\begin{array}{c}17 \\
(1.1)\end{array}$ & $\begin{array}{c}29 \\
(1.4)\end{array}$ & $\begin{array}{c}31 \\
(1.5)\end{array}$ \\
\hline Microtus montanus & $\begin{array}{c}11 \\
(0.7)\end{array}$ & 0 & $\begin{array}{c}6 \\
(0.6)\end{array}$ & 0 & $\begin{array}{c}4 \\
(0.3)\end{array}$ & $\begin{array}{c}11 \\
(0.7)\end{array}$ & 0 & $\begin{array}{c}10 \\
(0.5)\end{array}$ \\
\hline Sorex vagrans & 2 & $\begin{array}{c}8 \\
(0.5)\end{array}$ & $\begin{array}{c}16 \\
(1.1)\end{array}$ & 0 & 0 & 2 & $\begin{array}{c}8 \\
(0.5)\end{array}$ & $\begin{array}{c}16 \\
(1.1)\end{array}$ \\
\hline Eutamias minimus & 2 & 2 & 2 & 0 & 0 & 2 & 2 & 2 \\
\hline Mustela frenata & 1 & 2 & 1 & 0 & 0 & 1 & 2 & 1 \\
\hline Thomomys talpoides & 0 & 0 & 3 & 0 & 0 & 0 & 0 & 3 \\
\hline Clethrionomys gapperi & 0 & 1 & 0 & 0 & 0 & 0 & 1 & 0 \\
\hline \multicolumn{9}{|l|}{ Spring burn: } \\
\hline Peromyscus maniculatus & $\begin{array}{c}29 \\
(1.8)\end{array}$ & $\begin{array}{c}58 \\
(3.9)\end{array}$ & $\begin{array}{c}24 \\
(1.6)\end{array}$ & $\begin{array}{c}20 \\
(3.7)\end{array}$ & $\begin{array}{c}22 \\
(4.0)\end{array}$ & $\begin{array}{c}29 \\
(1.8)\end{array}$ & $\begin{array}{c}78 \\
(3.8)\end{array}$ & $\begin{array}{c}46 \\
(2.3)\end{array}$ \\
\hline Spermophilus armatus & $\begin{array}{c}12 \\
(0.8)\end{array}$ & $\begin{array}{c}7 \\
(0.5)\end{array}$ & $\begin{array}{c}29 \\
(1.9)\end{array}$ & $\begin{array}{c}2 \\
(0.4)\end{array}$ & $\begin{array}{c}9 \\
(1.7)\end{array}$ & $\begin{array}{c}12 \\
(0.8)\end{array}$ & $\begin{array}{c}9 \\
(0.4)\end{array}$ & $\begin{array}{c}38 \\
(1.9)\end{array}$ \\
\hline Zapus princeps & 1 & $\begin{array}{c}4 \\
(0.3)\end{array}$ & $\begin{array}{c}9 \\
(0.6)\end{array}$ & $\begin{array}{c}12 \\
(2.2)\end{array}$ & $\begin{array}{c}13 \\
(2.4)\end{array}$ & 1 & $\begin{array}{c}16 \\
(0.8)\end{array}$ & $\begin{array}{c}22 \\
(1.1)\end{array}$ \\
\hline Microtus montanus & $\mathbf{0}$ & 0 & $\begin{array}{c}20 \\
(1.3)\end{array}$ & 0 & 0 & 0 & 0 & $\begin{array}{c}20 \\
(1.3)\end{array}$ \\
\hline Sorex vagrans & 0 & 1 & $\begin{array}{c}10 \\
(0.7)\end{array}$ & 0 & 0 & 0 & 1 & $\begin{array}{c}10 \\
(0.7)\end{array}$ \\
\hline Eutamias minimus & $\begin{array}{c}4 \\
(0.3)\end{array}$ & 2 & 3 & 0 & 0 & $\begin{array}{c}4 \\
(0.3)\end{array}$ & 2 & 3 \\
\hline Mustela frenata & 1 & 2 & 0 & 0 & 0 & 1 & 2 & 0 \\
\hline Thomomys talpoides & 0 & 1 & $\mathbf{l}$ & 0 & 0 & 0 & 1 & 1 \\
\hline \multicolumn{9}{|l|}{ Fall burn: } \\
\hline Peromyscus maniculatus & $\begin{array}{c}14 \\
(0.9)\end{array}$ & $\begin{array}{c}284 \\
(18.9)\end{array}$ & $\begin{array}{c}305 \\
(20.3)\end{array}$ & $\begin{array}{c}113 \\
(10.5)\end{array}$ & $\begin{array}{c}157 \\
(14.5)\end{array}$ & $\begin{array}{c}14 \\
(0.9)\end{array}$ & $\begin{array}{c}397 \\
(19.5)\end{array}$ & $\begin{array}{c}462 \\
(22.7)\end{array}$ \\
\hline Spermophilus armatus & $\begin{array}{c}30 \\
(2.0)\end{array}$ & $\begin{array}{c}155 \\
(24.6)\end{array}$ & $\begin{array}{c}145 \\
(23.6)\end{array}$ & $\begin{array}{c}5 \\
(0.5)\end{array}$ & $\begin{array}{l}17 \\
(1.6)\end{array}$ & $\begin{array}{c}30 \\
(2.0)\end{array}$ & $\begin{array}{l}160 \\
(7.8)\end{array}$ & $\begin{array}{r}162 \\
(7.9)\end{array}$ \\
\hline Zapus princeps & $\begin{array}{c}4 \\
(0.3)\end{array}$ & 0 & 0 & $\begin{array}{r}7 \\
(0.7)\end{array}$ & $\begin{array}{c}4 \\
(0.3)\end{array}$ & $\begin{array}{c}4 \\
(0.3)\end{array}$ & $\begin{array}{c}7 \\
(0.3)\end{array}$ & $\begin{array}{c}4 \\
(0.2)\end{array}$ \\
\hline Microtus montanus & $\begin{array}{c}5 \\
(0.4)\end{array}$ & 0 & 0 & 0 & $\begin{array}{c}7 \\
(0.7)\end{array}$ & $\begin{array}{c}5 \\
(0.3)\end{array}$ & 0 & $\begin{array}{c}7 \\
(0.3)\end{array}$ \\
\hline Eutamias minimus & $\begin{array}{c}4 \\
(0.3)\end{array}$ & 0 & 0 & 0 & 0 & $\begin{array}{c}4 \\
(0.3)\end{array}$ & 0 & 0 \\
\hline Sorex vagrans & 2 & 0 & 0 & 0 & 0 & 2 & 0 & 0 \\
\hline Microtus longicaudus & 2 & 0 & 0 & 0 & 0 & 2 & 0 & 0 \\
\hline Mustela frenata & 1 & 0 & 0 & 0 & 0 & 1 & 0 & 0 \\
\hline Sorex cinereus & $i$ & 0 & 0 & 0 & 0 & 1 & 0 & 0 \\
\hline
\end{tabular}


Table 2. Percent coverage of major plant groups. Values are means for six sampling dates during the growing season.

\begin{tabular}{|c|c|c|c|c|c|c|c|c|c|}
\hline \multirow[b]{3}{*}{ Plant group } & \multicolumn{3}{|c|}{ Unburned control } & \multirow{2}{*}{\multicolumn{3}{|c|}{$\frac{\text { Spring burn }}{\text { Postburn }}$}} & \multicolumn{3}{|c|}{ Fall burn } \\
\hline & \multirow[b]{2}{*}{1974} & \multirow[b]{2}{*}{1975} & \multirow[b]{2}{*}{1976} & & & & \multirow{2}{*}{$\frac{\text { Preburn }}{1974}$} & \multicolumn{2}{|c|}{ Postburn } \\
\hline & & & & 1974 & 1975 & 1976 & & 1975 & 1976 \\
\hline Shrubs & 50 & 49 & 48 & 10 & 15 & 19 & 48 & 3 & 9 \\
\hline $\begin{array}{l}\text { Grass and grass-like } \\
\text { plants }\end{array}$ & 27 & 30 & 28 & 14 & 19 & 22 & 33 & 6 & 15 \\
\hline Forbs & 30 & 35 & 41 & 26 & 32 & 31 & 40 & 15 & 44 \\
\hline Total cover & 107 & 114 & 117 & 50 & 66 & 72 & 121 & 24 & 68 \\
\hline
\end{tabular}

occurrence of each group in the diet were calculated for each captured species.

\section{Results and Discussion}

Eight species of rodents, two species of insectivores, and one carnivore were captured during the 3-year period: deer mouse (Peromyscus maniculatus), Uinta ground squirrel (Spermophilus armatus), western jumping mouse (Zapus princeps), montane vole (Microtus montanus), least chipmunk (Eutamias minimus), longtailed vole (Microtus longicaudus), northern pocket gopher (Thomomys talpoides), masked shrew (Sorex cinereus), and longtailed weasel (Mustela frenata).

Information on species composition and abundance in the unburned sagebrush indicates that the small mammal community consists of a mixture of species whose total numbers varied little. Deer mouse and ground squirrel numbers varied most. There was little dietary overlap among species; different species were partitioned along the food dimension with Spermophilus (herbivore), Microtus (herbivore), Zapus (granivore), and Peromyscus (omnivore), each specializing in one food type (Fig. 1).

Following spring burning, total small mammal numbers were at low levels, but this was short-lived (Table 1). By the end of the second postburn year, densities were similar to unburned estimates with the responses being caused by one or two species. The unburned and partially burned islands that remained following the burn undoubtedly served as refuges for small mammals. Three years after spring burning, total cover of the understory was near unburned levels (Table 2), and small mammal numbers were approaching control values.

The fall burn differed from the spring burn in that no patches of unburned sagebrush remained and revegetation was slower. One year after burning, total cover was still dramatically lower than unburned estimates although deer mouse and ground squirrel captures had increased dramatically. It appears that the loss of cover had no negative effect on their densities, and that food may have been the factor affecting them most. Both deer mice and ground squirrels changed their food habits to utilize the increased availability of food. The absence of potentially competitive species may also have enhanced their success.

Species with rather specific niche requirements (e.g., voles, jumping mouse, shrews) cannot sustain populations on severe fall burns. Cook (1959) discovered that lack of cover following burning is the restricting factor in reducing vole populations, which require 1 year of mulch for runways. Jumping mice nest on the surface under protection of grasses and herbs (Burt and Grossenheider 1964), and Whittaker (1963) suggested that the absence of a welldeveloped, extensive herbaceous layer may exclude jumping mice.

Stout et al. (1971) correlated the absence of shrews on a burned coniferous forest in northern Idaho with their limited powers of dispersal and lack of ground litter on the burned sites. Stout's data also indicate a significantly reduced number of species of small mammals in the years following the burn.

Peromyscus maniculatus is particularly suited to exploit burns since it prefers seeds of grasses and herbs and insects (Drickamer 1970). Ahlgren (1966) contends that accumulations of seeds remain in unburned portions of forest floors and production by annual grasses is sufficient to support substantial populations of seedeating rodents. Many authors (Tevis 1956; Cook 1959; Gashwiler 1959) have shown that granivores a re favored in the initial stages of secondary succession following fire. Cook (1959) reported an irruption of western harvest mice (Reithrodontomys megalotis) during a period of maximum seed production. Both Cook (1959) and Lawrence (1966) have documented the shift in Peromyscus species abundance to favor $P$. maniculatus in the years following burning. Ahlgren (1966) and Beck and Vogal (1972) found significantly higher populations of $P$. maniculatus in other burned habitats. In addition, Ahlgren (1966) and Tester (1965) contend that burning improved habitat and food conditions for small rodents.

Kirkland (1976) describes a case of opportunism by $P$. maniculatus on mine wastes in New York and attributes its success to its ecological plasticity and the absence of congeneric competitors. The results from my study further illustrate the broad ecological tolerance of $P$. maniculatus and reflect the adaptability of this species in invading and exploiting harsh habitats. I attribute its success on the burns to increased immigration from surrounding areas and a maximization of reproductive potential (McGee 1976) in response to an increased availability of food.

These results support the contention that total small mammal numbers are not depleted by fire, but that there is a differential effect on the species present before burning. In my opinion, ideal sagebrush management should create a mosaic of different aged successional stages. The optimum proportion of unburned, spring and fall burned sites should mimic historic fire frequency and size where feasible. Consequently, no small mammal species, or group of similar species, will be significantly displaced in space and time.

\section{Literature Cited}

Ahlgren, C.E. 1966. Small mammals and reforestation following prescribed burning. J. Forest. 64:614-618.

Beck, A.M., and R.J. Vogl. 1972. The effects of spring burning on rodent populations in a brush prairie savanna. J. Mammal. 53:336-346.

Burt, W.H., and R.P. Grossenheider. 1964. A Field Guide to the Mammals. Houghton Mifflin Co., Boston. 284 p.

Canfield, R. 1941. Application of the line interception method in sampling range vegetation. J. Forest 39:388-390.

Cook, S.F. 1959. Effects of fire on a population of small rodents. Ecology 40: 102-108.

Daubenmire, R. 1959. A canopy-coverage method of vegetational analysis. Northwest Sci. 33:43-64.

Drickamer, L.C. 1970. Seed preferences in wild caught Peromyscus maniculatus bairdii and Peromyscus leucopus noveboracensis. J. Mammal. 51:191-194.

Gashwiler, J.S. 1959. Small mammal study in west-central Oregon. J. Mammal. 40:128-139.

Kirkland, G.L. 1976. Small mammals of a mine waste situation in the central Adirondacks, New York: a case of opportunism by Peromyscus maniculatus. Amer. Midl. Natur. 95:103-110.

Lawrence, C.E. 1966. Ecology of vertebrate animals in relation to chaparral fire in the Sierra Nevada foothills. Ecology 47:278-291.

McGee, J.M. 1976. Some effects of fire suppression and prescribed burning on birds and small mammals in sagebrush. Ph.D. Diss., Univ. Wyoming, Laramie. 134 p.

Stout, J., A.L. Farris, and V.L. Wright. 1971. Small mammal populations of an area in northern Idaho severely bumed in 1967. Northwest Sci. 45:219-226. 
Taylor, D.L. 1969. Biotic succession of lodgepole pine forests of fire origin in Yellowstone National Park. Ph.D. Diss., Univ. Wyoming, Laramie. $320 \mathrm{p}$.

Tester, J.R. 1965. Effects of a controlled burn on small mammals in Minnesota oak-savanna. Amer. Midl. Natur. 74:240-243.
Tevis, L. 1956. Responscs of small mammal populations to logging of Douglas-fir. J. Mammal. 37:189-196.

Whittaker, J.0. 1963. A study of the meadow jumping mouse Zapus hudsonius (Zimmerman), in central New York. Ecol. Monogr. 33:215254. 